\title{
Fiscal Decentralisation and Economic Development in Nigeria: The Role of Democratic Institution
}

\author{
Hammed A. Adefeso ${ }^{1} \&$ Tunde A. Abioro ${ }^{1}$ \\ ${ }^{1}$ Department of Local Government Studies, Faculty of Administration, Obafemi Awolowo University, Ile-Ife, \\ Nigeria \\ Correspondence: Hammed A. Adefeso, Department of Local Government Studies, Faculty of Administration, \\ Obafemi Awolowo University, Ile-Ife, Nigeria. Tel: 234-80-3806-3669. E-mail: adefesoha@yahoo.com
}

Received: August 20,2015 Accepted: October 22, $2015 \quad$ Online Published: February 28, 2016
$\begin{aligned} & \text { doi:10.5539/jpl.v9n1p1 } \\ & \text { URL: http://dx.doi.org/10.5539/jpl.v9n1p1 }\end{aligned}$

\begin{abstract}
It is a time series analysis that investigates on the role of democratic institution in the relationship between fiscal decentralisation and economic development in Nigeria. The trend analysis clearly showed that sub-national expenditure is higher than sub-national revenue in Nigeria. The federally allocated expenditures to sub-national is far more than its corresponding allocated revenue in Nigeria and this becomes manifest from the year 1999 when the nation returned to civil rule up till 2014 under the administration of a dominant political party known as the People's Democratic Party (PDP). Using multiple regression analysis, the empirical results revealed 1\% increase in expenditure decentralisation and revenue decentralisation would retard economic performance by $11 \%$ and $21 \%$ respectively when democratic institution index is included as explanatory variable. The impact of democratic institution in the relationship between fiscal decentralisation and economic performance in Nigeria is however, weak, positive and statistically insignificant in Nigeria as $100 \%$ increase in expenditure decentralisation and revenue decentralisation only yield $4 \%$ and $5 \%$ economic performance respectively in Nigeria. This has resulted to a wide spread level of corruption in Nigeria among bureaucrats and politicians. The study therefore advocates for a strong government institution that will be transparent, accountable and also respect the rule of law for sustainability, effectiveness and timely service delivery.
\end{abstract}

Keywords: fiscal decentralisation, economic development, democratic institution, Nigeria

\section{Introduction}

Fiscal decentralisation is the devolution of expenditures functions and tax revenue sources from the national government to sub-national government has been on the policy agendas of Nigeria and other developing and transitional economies as well as OECD countries in the recent decade to promote national development objectives (Oates, 1994; Murphy, 1995). Infact, out of seventy-five developing and emerging economies with populations greater than five million, all but twelve claim to have embarked on some type of transfer of power to local governments (Dillinger, 1994; Davoodi and Zou, 1998; Rodriguez-Pose and Kroijer, 2009) so as to escape the traps of inefficient governance, which would in turn lead to macroeconomic instability and insufficient growth and development. This theoretical expectation from fiscal federalism has made it to now be in vogue as both the developed and developing countries are turning to devolution to improve the development of their public sectors (Oates, 1999) through economic development and democratic governance.

As noted in literature, there is a clear linkage between fiscal decentralisation and democratic governance as fiscal decentralisation reinforces democratic institutions by bringing governance closer to the people and by providing various communities with the means to take decisions that affect their daily lives. Democratic governance provides the necessary condition for the realization of efficiency gains associated with fiscal federalism as it is through election of public officials, other democratic institutions like referendum and poll that the tax payers reveal their preferences for goods and services as well as their willingness to pay for them. These regional and local officials are equally held responsible and accountable to the taxpayers and electorates through democratic governance. Infact, according to Putman (1993), while decentralisation improves democracy, fiscal decentralisation needs democratic governance to realise the advantages with efficient provision of public services. Though the concept of economic development has historically remained a difficult task, however there has been an agreement that it means advancement in human and environmental conditions. Development is more 
than the statistical and mathematical increment in a country's Gross Domestic Product (GDP) but fundamentally a progressive improvement in the standard and condition of living of masses and their environment. The development is however achieved when the necessary governmental structures, appropriate and effective policies and public spending by both the central and sub-national governments. The structure of governance process in the federal state like Nigeria where there is simultaneity of opportunities and challenges have made it a veritable case for economic development. This is because the three tiers of government (federal, state and local) have overlapping but autonomous fiscal and policy jurisdiction for basic public services that positively affect economic development.

The efforts towards the achievement of development will be hindered or accelerated depending on the synergy and coordination of policies and service delivery across the levels of government in the country. Since, the state government and local government in particular, in Nigeria are the closest government to the grassroots in terms of providing basic public services, their actions or inactions could impact on the sustainable economic growth and development. Obviously, while literatures have established that Fiscal decentralisation provides means for effective democratic governance and the quality of governance which is a function of democracy is highly correlated with economic growth and development but whether or not there is any significant economic growth and development gained associated with fiscal decentralization has not been established in the literature. The study shall employ multiple regression analysis on fiscal decentralisation-Governance-Development nexus in Nigeria. It is of greater priority to investigate this interaction within the Nigerian economy which is one of the most decentralised countries in the world, Rodden, (2003) in Saibu and Adedokun (2010). The nature of fiscal federalism in Nigeria has generated intense debate, characterised by constant struggle, clamour for change and sometimes violence in the form of resource control. However, the agitations for more decentralised fiscal arrangement by lower tiers of government have continued to be resisted by a leviathan central government and this has led to the setting up of many commissions and committees in Nigeria since 1946. All of these have resulted to the recent process of granting the local government autonomy which has attracted a lot of controversy among the stakeholders in Nigeria.

\section{Fiscal Federalism in Nigeria: An Overview}

There is no generally acceptable definition of the term federalism; however, K.C Wheare's definition is leading and instructive. In his seminal book titled; "Federal Government" he avers that federalism is a method of dividing powers so that general and regional governments are each within a sphere, coordinate and independent (Wheare: 1964: 33). Other definitions that guide the concept as related to this study are found in the works of William Riker who opines that it is a system of government consisting of autonomous units that are tied together within one country (Steiner: 1995: 123). While, Dyke gave a formal perspective to it and conceive it as a division of power between central and regional governments such that neither is subordinate to other (Dyke, 1996: 69). However, meeting the expectations and demands of the citizenry prompts up interaction among all the levels of government where the ability and capability to meet the responsibilities are looked at as well as contradictions and challenges that follows. Generally, federalism as a concept of governance is a political and administrative framework in which power is shared by different constituent units of a federating union which are supposedly or relatively autonomous. Thus, when demands on government and the need to meet them adequately and promptly arise, a proper division of functions according to the corresponding financial powers between the different levels of government becomes imperative.

It is essential to understand the concept of fiscal federalism in Nigeria parlance which sees it as the division of powers, functions, duties and financial resources among the different levels of government, namely: federal, state and local governments in a federation (Ihedioha: 2013). Thus, it is the application of the federal principles in resource mobilization and allocation within and among the constituent units in the federation in an arrangement that involves intergovernmental fiscal relations. A discourse on fiscal federalism cannot escape the analysis of revenue allocation and the agitation for resource control by levels of government and other interest/ pressure groups. The kind of interaction that has subsisted in the country has led to the agitation for fiscal autonomy, power and responsibility among the levels of government and such is not only restricted to Nigeria as it can be found in any federal system. Supporting this view, Ronald Watts (1970 cited by Omotoso, 2010: 247) states that federal finance is an extremely important and controversial subject because: first, it affects the allocation of administrative responsibility because the financial resources available will place limits on the scope of administration which either level of government is able to sustain; second, it affects the political balance and third, it is significant also because the assignment of fiscal and expenditure powers will determine which governments are able to use these instruments to control the economy. 
An overview of the journey to the state of the nation's present revenue allocation is essential as various formulae have at one time or the other been adopted. Of note, in recommending a revenue allocation formula, factors that are generally considered include the derivation and need principles that can foster and ensure equity to all sections of the country. Omotoso (2010) opine that Nigerian revenue allocation formula is based on two major principles: equity principle which include even development, national interest, continuity in government service, minimum responsibility of government, financial comparability, national minimum standard, landmass and terrain as well as the efficiency principle that considers derivation, independent revenue, absorptive capacity, tax effort and fiscal efficiency. Notably, revenue sharing practices in Nigeria emphasizes equity over efficiency as it is the case in most developing nations.

In the Nigerian situation, agitations and counter agitations by political pundits and pressure groups have led to constant review of the revenue allocation such that between 1946 and 2004, a couple of commissions and committee have held sway on the matter among which are:

1) Sydney Phillipson Commission (1946): This commission introduced three principles, namely: derivation, development process and population. By derivation, it means each unit of government would receive from the central purse a proportion of its contributions to the central pool and the commission went further to identify sources of revenue collected by the federal government to include customs and excise duties and those revenue that have implication on national policy etc. the criticism that followed this provisions led to another commission in 1951 chaired by both Sydney Phillipson and Hicks Phillipson to come up with a more acceptable revenue allocation formula

2) Hicks Phillipson Commission (1951): This commission recommended four general principles which are: independent revenue, derivation, need and national interest as the criteria for revenue sharing. It was also criticized over the control of government collection of duties and tax on Premium Motor Spirit

3) Louis Chicks Commission (1953): This commission was to adjust the previous recommendations and thus came up with a main principle and it expatiated derivation

4) Raisman commission (1957/58): This commission arose from complaints and dissatisfaction with the derivation principle and subsequently led to the creation of distributive pool account and complete regional jurisdiction over personal income tax. It further recommended need balanced development and minimum responsibility with a percentage division of $40 \%$ to the north, $31 \%$ to the east, $24 \%$ to the west and $5 \%$ to the southern Cameroon.

5) Binns Commission (1964): This commission however rejected the principles of need and derivation; it thus increased the percentage of general import revenue, mining rent and royalties payable to the derivation pool account from $30 \%$ to $35 \%$ and further recommended percentage division of $42 \%$ to the north, $30 \%$ to the east, $20 \%$ to the west and $8 \%$ to the mid-west

6) Dina commission (1968): This commission was to look into the distribution of revenue following the splitting of the nation into twelve states. It however renamed Distribution Pool Account to State Joint Account and also created special grant account and advocated for a permanent planning and fiscal commission. It also recommended national minimum standards, balanced development, basic need and national interest in the distribution of revenue

7) Aboyade Technical Committee (1977): This commission also supported national minimum standard for national integration. The committee recommended for all the federally collected revenues to be pooled into the federation account and be allocated there from among the federal, state and local governments. It is noteworthy, here, that the local government started receiving their revenue allocation directly from federation account as the third tier of government after the Aboyade's committee submission of its requirement for the share proportion of $57 \%, 30 \%$ and $10 \%$ for federal, state and local government respectively with the remaining $3 \%$ for special grant.

8) Pius Okigbo Commission (1980): This commission is saddled with the responsibility of looking into the derivation, even development equitable distribution and national interest as well as make recommendation on revenue sharing formula among the levels of government. It thus recommended percentages on principle of population, social development and internal revenue efforts. it recommended revenue allocation sharing formula to be $53 \%, 30 \%$ and $10 \%$ for the federal, state and local governments respectively and also recommended $7 \%$ as special fund which should be distributed among Federal Capital Territory (FCT), mineral producing areas, derivation, ecological problems, and revenue equalization fund (Okigbo; 1980). On its acceptance, the federal government effected some changes as $53 \%, 35 \%$ and $10 \%$ for federal state and local government respectively. The government directed that the state revenue allocation of $35 \%$ should be applied as follows; equality of states $30.5 \%$, ecological problems $-1.0 \%$, and derivation principle $-3.5 \%$. (Ugwu, 2012). This system of revenue 
allocation formula, just as the previous ones, the commission also received political and social criticisms but the federal military government through their decree only effected changes regarding to derivations. Derivation of $2 \%$ was to be drawn from revenues relating directly to the state in which minerals were extracted while $1.5 \%$ went into fund for the development of mineral producing areas of the country.

9) Revenue Mobilization Allocation and Fiscal Commission (1988): This commission introduced the principles of; equality of states, population, social development factor, landmass and terrain, internal revenue efforts and special fund. It recommended federal government gets $(50 \%)$, states $(30 \%)$, local governments $(15 \%)$ and special fund $(5 \%)$

The revenue sharing journey in the country have however seen other laws and decrees promulgated; among which are; decree 15 of 1967, 13 of 1970, 9 of 1971, 6 of 1776 and 7 of 1975 (Oyeneye, et al 1988 cited in Ihedioha, 2013). The 1992 Revenue Allocation Formula as amended by various intervening issues like the 1999 constitution, supreme court judgment and presidential adaptation orders are parts of the defining characters of allocation of resources in the country today. Noteworthy, by decree 106 of 1992, the revenue allocation formula before the coming into effect of 1999 constitution was (a) Federal government- $48.5 \%$ (b) State government- $24 \%$ (c) local government- $20 \%$ (d) Special fund $7.5 \%$ with the $7.5 \%$ special fund sub-divided into (i) Federal capital territory- $1 \%$ (ii) Development of mineral producing areas based on derivation- 3\% (iii) General ecological problems-2 \% (iv) Derivation 1\% (v) Stabilization account- $0.5 \%$.

In the meantime, section 153 of the (1999) Nigerian constitution provide for the establishment of certain federal executive bodies, sub-section (1n), provide for revenue mobilization allocation and fiscal commission with functions, composition and powers, as provided in the third schedule of Part 1. As stated in section 32 of the schedule among others states; review from time to time the revenue allocation formula and principles in operation to ensure conformity with changing realities. After a court case decided by the supreme court that nullified the allocation of $7 \%$ of the federal allocation to special fund, President Obasanjo on $8^{\text {th }}$ May, 2002 by an order: Allocation of Revenue (federation account etc) changed the existing formula to federal government $56 \%$, state government $24 \%$, local governments $20 \%$ with $13 \%$ to be used for derivation pursuant to the provision of section 162 (2) of the country. The federal government's $56 \%$ was further explained as being sub-divided in the following manner: federal government $48.50 \%$, general ecological problems $2 \%$, federal capital territory $1 \%$, stabilization account $1.5 \%$, and development of natural resources $3 \%$.

By the month of July, 2002 there was another order that modified the previous order that shared the revenue as: federal government $54.68 \%$, state government $24.72 \%$ and local governments $20.6 \%$. By March 2004, the Revenue Allocation Formula was again modified by a circular from the Ministry of Finance putting revenue sharing formula as: federal government $52.68 \%$, state government $24.72 \%$ and local government $20.6 \%$ which is still in use till date (Ihedioha; 2013). In practice, fiscal decentralization which mirrors the amount of fiscal autonomy and responsibility accorded to sub-national government, has been an important subject in the policy equation of many developing, transition, and developed countries.

\section{Empirical Evidence and Modelling Framework}

Since the empirical evidence on fiscal decentralisation and economic activities nexus have been well documented elsewhere to date (see for example Feld et al. 2014), the model specification for this study followed Davoodi and Zou (1998) which used the endogenous growth framework to analyse the development effect of fiscal decentralisation. This study extends Barro's (1990) endogenous growth model by assuming that public spending is carried out by three levels of government: federal, state and local which is in conformity with Nigerian case. The total government spending is carried out by federal, state and local government. Thus total government spending is divided into three components: federal level, state level and local level government spending. The regression that is estimated on the time series data using the OLS technique of analysis is specified as follows:

$$
g_{t}=\alpha+\delta_{1} m_{t}+\delta_{2} \tau_{t}+\varepsilon_{t}
$$

The economic benefits of fiscal decentralisation policy - through enhancing the efficiency of the public goods and services provision by matching the local citizen preferences; by increasing competitions among the local governments; by reducing corruption and by enhancing accountability which will promote developmental process - can only be materialised if the process of FDP is complemented strong institution like good governance. The role of democratic governance is very crucial in making the theorem of decentralisation applicable. The study of Iimi (2005) further extends this framework by incorporating the interactive term of fiscal decentralisation and political institutions in the model. Following Iimi (2005), the following model to capture the link among fiscal decentralisation, democratic governance and economic development is specified as 


$$
g_{t}=\delta_{0}+\delta_{1} \tau_{t}+\delta_{2} m_{t}+\delta_{3} d_{t}+\delta_{4} m_{t} * d_{t}+\varepsilon_{t}
$$

There is the need to include vector of control variables that have been frequently used in the literature as identified by Sala-i-Matin (1997), Barro amd Lee (1996), Mankiw, et al. (1992) and Levine and Renelt (1992). Specifically, Levine and Renelt (1992) have identified some important control variables that are sensitive to growth regression analysis. The vector $x_{t}$ consists of those set of control variables. This study however, shall employ the size of the labour force, the investment rate, external influence and a measure of the openness of the economy. Taking this into consideration, the above equation 3.14 shall transform as specified below

$$
g_{t}=\delta_{0}+\delta_{1} \tau_{t}+\delta_{2} m_{t}+\delta_{3} d_{t}+\delta_{4} m_{t} * d_{t}+\delta_{5} x_{t}^{\prime}+\varepsilon_{t}
$$

Where $t$ isthe number of time periods i.e. $(\mathrm{t}=1,2 \ldots \ldots \mathrm{N}) . \delta_{0}, \delta_{1}, \delta_{2}, \delta_{3}, \delta_{4}$, are scalar parameters while $\delta_{5}$ is a vector of the parameters to be estimated. $g_{t}$ is per capital output growth rate, $m_{t}$ is the measureoffiscal decentralizationand $\tau_{t}$ is the tax rate, $d_{t}$ captures democratic governance while $m_{t} * d_{t}$ is the interaction term between fiscal decentralisation and democratic institution which is of particular interest to this study. $x_{t}^{\prime}$ is a vector of control variables and $\varepsilon_{t}$ is the disturbance term that is assumed to be serially uncorrelated and orthogonal to the explanatory variables. The focus of this research is the coefficient $\delta_{2}$ on the fiscal decentralization variable, which may be positive or negative and statistically significant given the conventional arguments in favour or against of fiscal decentralization policy. Also, in this model, the interactive term, $m_{t} *$ $d_{t}$ is used to determine the role of democratic institution on the nature of relationship between fiscal decentralisation and economic development in Nigeria. The rationale behind the interaction term is that the governance quality affects the efficiency of fiscal decentralisation and hence economic development. The magnitude effect fiscal decentralisation on development is thus:

$$
\frac{\partial g_{t}}{\partial m_{t}}=\delta_{2}+\delta_{4} * d_{t}
$$

\section{Sources of Data and Econometric Analysis}

This study is based on time series data covering the period of 1970 to 2014 which made up for 44 years. Table 1

\begin{tabular}{|c|c|c|}
\hline Variables & Indicators & Sources \\
\hline Economic Development & Real GDP per capital & $\begin{array}{l}\text { Statistical Bulletin published by Central Bank } \\
\text { of Nigeria }\end{array}$ \\
\hline Fiscal Decentralization & $\begin{array}{l}\text { (i)Expenditure decentralisation } \\
\text { (ii) Revenue decentralisation }\end{array}$ & $\begin{array}{l}\text { Calculated from Statistical Bulletin published } \\
\text { by Central Bank of Nigeria }\end{array}$ \\
\hline Tax rate & $\begin{array}{l}\text { Ratio of the total consolidated receipts of } \\
\text { government(i.e. net of intergovernmental } \\
\text { grants) to GDP }\end{array}$ & $\begin{array}{l}\text { Calculated from Statistical Bulletin published } \\
\text { by Central Bank of Nigeria }\end{array}$ \\
\hline $\begin{array}{l}\text { Size of the labour force (initial } \\
\text { human capital) }\end{array}$ & Secondary school enrolment rate & $\begin{array}{l}\text { Statistical Bulletin published by Central Bank } \\
\text { of Nigeria }\end{array}$ \\
\hline Trade Openness & Import + Export/GDP & $\begin{array}{l}\text { Calculated from Statistical Bulletin published } \\
\text { by Central Bank of Nigeria }\end{array}$ \\
\hline Democratic Institution & Democracy Index & Polity IV \\
\hline
\end{tabular}
below shows the variables employed for the estimation of the analysis and its corresponding sources.

Table 1. Variables employed for the estimation and sources

Source: Author's Compilation (2016)

\subsection{Fiscal Decentralisation Measure}

The two widely used measures of fiscal decentralisation are expenditure decentralisation and revenue decentralisation. The expenditure decentralisation (ED) is defined as the ratio of sub-national expenditure to consolidated government expenditure and revenue decentralisation (RD) is the ratio of sub-national revenue to 
consolidated government revenue. Notably, revenue decentralisation has been relatively considered because of its reflection of local government autonomy however both variables are often employed as index of fiscal decentralisation measure.

$$
\text { Revenue Decentralisation }(\mathrm{RD})=\frac{S G R+L G R}{F G R+S G R+L G R}
$$

Where FGR, SGR, and LGR represent Federal Government Revenue, State Government Revenue and Local Government Revenue respectively. Figure 1 shows the trend in revenue decentralization in Nigeria. The share of sub national revenue in consolidated government revenue ranges from $0.20 \%$ to $0.40 \%$ until 1998 and thereafter showing an increasing trend to reach $0.77 \%$ in 2009 . After this period, revenue decentralisation decreases to about $0.59 \% \ln 2014$.

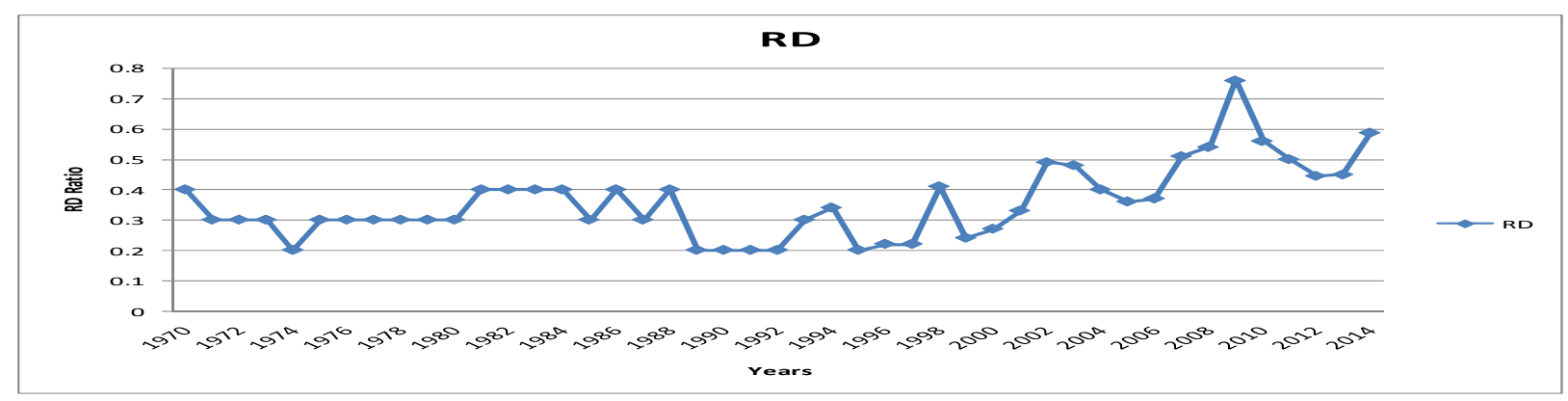

Source: Authors' Computation (2015)

Figure 1. Revenue decentralisation in Nigeria

The expenditure decentralisation on the other hand is measured as follows:

$$
\text { Expenditure Decentralisation }(\mathrm{ED})=\frac{S G E+L G E}{F G E+S G E+L G E}
$$

Where FGE, SGE, and LGE represent Federal Government Expenditure, State Government Expenditure and Local Government Expenditure respectively. Figure 2 shows the trend in expenditure decentralization in Nigeria. The share of sub national expenditure in consolidated government revenue ranges from $0.30 \%$ in 1970 reaches peak of $1.20 \%$ in 1983 drops to $70 \%$ in 1984 and thereafter it ranges between $0.50 \%$ and $0.22 \%$ in 2000 and thereafter there has been upward trend reaches peak ofabout $1.35 \%$ in 2007 and 2014 .

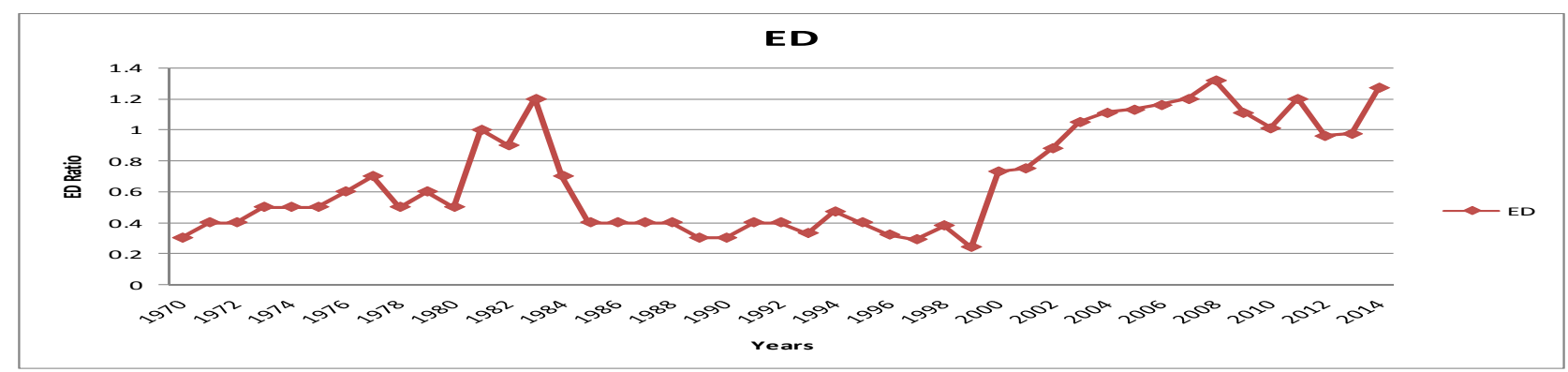

Figure 2. Expenditure decentralisation in Nigeria

Source: Authors' Computation (2015)

\subsection{Trend Analysis of Fiscal Decentralisation in Nigeria}

The history of Nigerian fiscal decentralization captured with the plot below depict that sub-national expenditure decentralization (ED) is far more decentralized that sub-national revenue decentralization (RD). The plot clearly show sub-national expenditure is higher than sub-national revenue in Nigeria. The federally allocated expenditures to sub-national is far more than its corresponding allocated revenue in Nigeria and this becomes manifest from the year 1999 when theup till date under the administration of a dominant political party known as People Democratic Party (PDP) as shown in figure 3. 


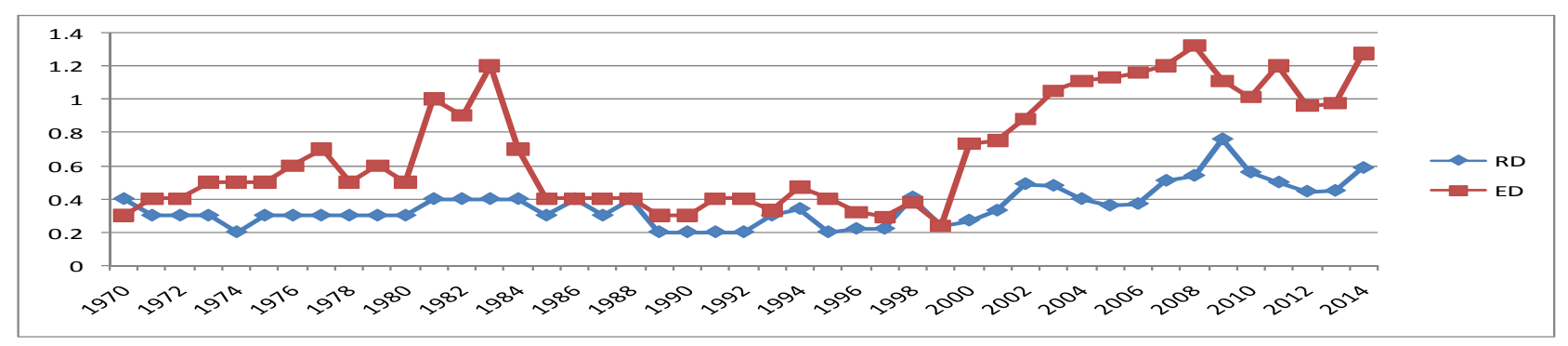

Figure 3. Trend analysis of fiscal decentralisation measures in Nigeria

Source: Authors' Computation (2015)

\section{Empirical Analysis and Estimation}

This section comprises of the discussion of the estimation results obtained in this study. It provides statistical interpretation of some selected variables employed in the analysis and the estimated results which were all discussed in detail.

\subsection{Descriptive Analysis}

The relevant data set employed on 45 years of annual observations from 1970 to 2014 on the variables employed. Table 2 reports the descriptive statistics on the selected variables. The average growth of GDP per capital is $16 \%$ with variation of $19 \%$ for the period of study. It moves from $-0.5 \%$ in 1970 to $72 \%$ in 2014 . On the average the Tax to GDP (LT/GDP) is $314 \%$ with the standard deviation of $52 \%$ within the range of $186 \%$ and $404 \%$. Likewise, the average value for democratic governance (DG) is -1.636 which move from -88.0 to 8.0 with variation of 19.25 . However, when it interacts with expenditure decentralisation (DG*EFD) and revenue decentralisation (DG*RFD), it average values change to 0.466 and -0.429 and move from -44.0 and -36.08 with standard deviation of 9.108 and 6.971 respectively. The means proxies of fiscal decentralisation, expenditure fiscal decentralisation (LEFD) and revenue fiscal decentralisation (LRFD) are $-49 \%$ and $-108 \%$ respectively. While LEFD moves from $-142 \%$ to $27 \%$ with $50 \%$ variation, LRFD ranges from $-160 \%$ to $-27 \%$ with $33 \%$ variation over the period of study. Likewise, the mean of human capital proxied by secondary school enrolment rate (LENTR) and globalization captured by degree of openness (OPNESS) are $306 \%$ and $408 \%$ respectively.

Table 2. Descriptive Statistics

\begin{tabular}{|c|c|c|c|c|c|c|c|c|c|}
\hline & (LGDPK) & LT/GDP & DG*EFD & DG*RFD & DG & LEFD & LRFD & LENRT & LOPNESS \\
\hline Mean & 0.166300 & 3.144200 & 0.466991 & -0.42989 & -1.636364 & -0.495221 & -1.086481 & 3.069124 & 4.080473 \\
\hline Median & 0.133609 & 3.111611 & 0.000000 & 0.00000 & 0.000000 & -0.601986 & -1.156318 & 3.291680 & 4.055312 \\
\hline Maximum & 0.728448 & 4.047863 & 9.600000 & 3.20000 & 8.000000 & 0.277632 & -0.274437 & 3.814527 & 4.605321 \\
\hline Minimum & -0.556321 & 1.867520 & -44.0000 & -36.0800 & -88.00000 & -1.427116 & -1.609438 & 1.559859 & 3.809862 \\
\hline Std. Dev. & 0.199098 & 0.520201 & 9.10873 & 6.97172 & 19.25724 & 0.504717 & 0.333534 & 0.635440 & 0.165822 \\
\hline Skewness & -0.283065 & -0.318687 & -3.87280 & -4.333575 & -4.219410 & 0.036933 & 0.107646 & -1.140442 & 1.213163 \\
\hline Kurtosis & 6.455766 & 2.718851 & 18.14111 & 20.8643 & 19.26304 & 1.624242 & 2.472267 & 3.018373 & 4.515107 \\
\hline Jarque-Bera & 22.48184 & 0.889696 & 530.2870 & 722.7990 & 615.4501 & 3.479974 & 0.595564 & 9.538406 & 15.00145 \\
\hline Probability & 0.000013 & 0.640922 & 0.000000 & 0.000000 & 0.000000 & 0.175523 & 0.742463 & 0.008487 & 0.000553 \\
\hline
\end{tabular}

Source: Authors' Computation (2015)

While the LENTR moves from $155 \%$ to $381 \%$ with $63 \%$ variation, OPNESS fluctuates from $380 \%$ to $460 \%$ with $16 \%$ variation over the period of study. The skewness of the variable measures the asymmetry of the distribution of the series around the mean. Almost all variables were little bit skewed. LEFD, LRFD and LOPNESS were positively skewed while LGDPK, DG, EFD*DG, RFD*DG LT/GDP were negatively skewed. The variables that were negatively skewed were more than those that were positively skewed which indicated that the data sets had long left tail. Kurtosis statistic measures the peakness or flatness of the distribution of a series was far greater 
than the standard 3.0. By implication, LGDPK, DG, EFD*DG, RFD*DG and LENRT were high peaked or lepto-kurtic distribution but LT/GDP, LRFD and OPNESS had approximately normal distribution while the shape of distribution for LEFD was platy-kurtic. Being peaked, however, was an indication that there were very few observations within the region where the median value resided. Jarque-Bera is a statistic for testing joint hypothesis of Skewness and Kurtosis by determining whether a series is normally distributed or not. It measures the difference of the skewness and kurtosis of the series from normal distribution. The Jarque-Bera statistic values of LGDPK, DG, EFD*DG, RFD*DG OPNESS, ENRT had their probability values less than 0.01 (i.e. $\mathrm{p}<0.01)$. It means that the null hypothesis of normality in the distribution was rejected i.e. the residuals of all these variables embedded in this analysis were not normally distributed.

Table 3. Correlation matrix

\begin{tabular}{ccccccc}
\hline & LT/GDP & DG & LEFD & LRFD & LENRT & LOPNESS \\
\hline LT/GDP & 1.000000 & & & & & \\
DG & 0.160053 & 1.000000 & & & & \\
LEFD & 0.438355 & 0.227337 & 1.000000 & & & \\
LRFD & 0.148836 & 0.044702 & 0.742021 & 1.000000 & & \\
LENRT & 0.750446 & 0.124670 & 0.388234 & 0.365748 & 1.000000 & \\
LOPNESS & 0.060712 & -0.110471 & 0.278604 & 0.176186 & 0.024015 & 1.000000 \\
\hline
\end{tabular}

Source: Authors' Computation (2015)

The Table 3 represents the degree of association among the explanatory variables employed. The result indicates that there is absence of the problem of multicollinearity as the high coefficient of correlation $\left(R_{X_{1} X_{2}} \geq 80\right)$ indicates severity of multicollinearity problem. The interactive terms EFD*DG and RFD*DG are highly correlated with $R_{X_{1} X_{2}}=0.95$. However, these variables are used in separate equations so the problem of multicollinearity does not arise.

Table 4. Unit root test (ADF Test)

\begin{tabular}{|c|c|c|c|}
\hline Variables & At Level & At First Difference & Remark \\
\hline LGDPK & -0.9120 & $-6.2153 * * *$ & $I(1)$ \\
\hline$D G$ & $-6.7594 * * *$ & -------- & $I(0)$ \\
\hline$E F D * D G$ & $-6.1311 * * *$ & --------- & $I(0)$ \\
\hline$R F D * D G$ & $-6.5333 * * *$ & -------- & $I(0)$ \\
\hline$L E F D$ & -1.9249 & $-8.3484 * * *$ & $I(1)$ \\
\hline LERD & $-2.6506^{*}$ & ----------- & $I(0)$ \\
\hline LENTR & $-2.9323^{* *}$ & ----------- & $I(0)$ \\
\hline LOPNESS & $-3.0855^{*}$ & ------------ & $I(0)$ \\
\hline$L T / G D P$ & $-3.2908^{*}$ & ------------ & $I(0)$ \\
\hline
\end{tabular}

Note: $* * *, * * *$ denote significant level at $10 \%, 5 \%$ and $1 \%$ respectively.

Source: Authors' Computation (2015)

Table 4 tests for the order of integration of the variables which appear in our models. In other to characterize the time series property of the variables of our interest, Augmented Dickey Fuller (ADF) test was employed. Most of the variables are regarded as stationary at their levels at different significant levels except LGDPK and LEFD which reached stationarity at first difference. 


\subsection{Empirical Results}

The result of empirical analysis is shown in Table 5. The result showed that fiscal decentralisations indices are negatively correlated with economic performance in Nigeria when democratic institution index is included as part of explanatory variables. Specifically, $1 \%$ increase in expenditure decentralisation and revenue decentralisation would retard economic performance by $11 \%$ and $21 \%$ respectively. The impact of democratic institution in the relationship between fiscal decentralisation and economic performance in Nigeria is weak, positive and statistically insignificant in Nigeria. As shown in the Table 5, 100\% increase in expenditure decentralisation and revenue decentralisation only yield $4 \%$ and $5 \%$ economic performance respectively in Nigeria. This may be attributed to the fact that the wide spread of corruption in Nigeria among politicians is one of the products of a weak government institution.

Table 5. Estimated result

Dependent Variable: D(LGDPK)

\begin{tabular}{|c|c|c|c|c|}
\hline Variables & (1) & (2) & (3) & (4) \\
\hline \multirow[t]{2}{*}{ Constant } & $-0.3767 * * *$ & -0.2199 & 0.8320 & 0.9301 \\
\hline & $(-1.734)$ & $(-1.0411)$ & $(0.5143)$ & $(0.6336)$ \\
\hline \multirow[t]{2}{*}{$L R F D$} & $-0.2306^{* *}$ & ----------- & $-0.2189 * *$ & ----------- \\
\hline & $(-2.655)$ & & $(-2.417)$ & \\
\hline \multirow[t]{2}{*}{$D(L E F D)$} & ------------ & $-0.1118 * * *$ & ---------- & $-0.1316 * * *$ \\
\hline & & $(-1.75112)$ & & $(-1.9384)$ \\
\hline \multirow[t]{2}{*}{$L T / G D P$} & 0.0930 & $0.1052 * * *$ & 0.1024 & $0.1612 * *$ \\
\hline & (1.670) & (1.6995) & (1.565) & $(2.4114)$ \\
\hline \multirow[t]{2}{*}{$E F D * D G$} & & & & 0.0045 \\
\hline & & & ---------- & $(0.9134)$ \\
\hline \multirow[t]{2}{*}{$R F D * D G$} & & & 0.0051 & \\
\hline & & & $(0.5431)$ & ------------- \\
\hline \multirow[t]{2}{*}{ LENTR } & & & -0.0197 & -0.0738 \\
\hline & & & $(-0.286)$ & $(-1.255)$ \\
\hline \multirow[t]{2}{*}{ LOPNESS } & & & -0.2857 & -0.2730 \\
\hline & & & $(-0.9225)$ & $(-0.739)$ \\
\hline Observation & 44 & 44 & 44 & 44 \\
\hline Adjusted $R^{2}$ & 0.12 & 0.050 & 0.179 & 0.1185 \\
\hline D.W. & 2.17 & 2.20 & 1.98 & 1.97 \\
\hline
\end{tabular}

Source: Authors' Computation (2015)

\subsection{Policy Recommendation}

This study is of the opinion that the effects of a number of intervening variables such as the nature of the bureaucracy and other institutions, various groups competing for values and resources, type of ruling elite and their orientations, ideology, parasitic godfathers among other things have created the present stage of challenges occasioned in the fiscal and economic sector. Therefore, for an improved performance, the study recommends strong institutions that can implement governmental policies and programmes. Also, democratic norms such as transparency, accountability, probity and rule of law are urgently required.

\section{References}

Borro, R. (1990). Government Spending in a Simple Model of Endogenous Growth.Journal of Political Economy, 98(2), 103-125. http://dx.doi.org/10.1086/261726

Davoodi, H., \& Zou, H. (1998). Fiscal Decentralization and Economic Growth: A Cross-Country Study.Journal 
of Urban Economics, 43(2). http://dx.doi.org/10.1006/juec.1997.2042

Dillinger, W. (1994). Decentralization and its Implication for Urban Service Delivery, Urban Management Programme, Discussion Paper No. 16, The World Bank, Washington D.C.

Dyke, P. (1996). Canadian Politics: Critical Approaches. Scarboroughont: Nelson.

FGN. (1999). Federal Republic of Nigeria, Constitution of the Federal Republic of Nigeria, Official Gazette, Vol: $8-6$, no 27.

Ihedioha, E. (2013). Legislative Issues in Fiscal Federalism in Nigeria, Paper Delivered at the Second Anniversary Lecture of the Fifth Assembly of the Delta State House of Assembly, International Convention Centre, Asaba.

Iimi, A. (2005). Decentralization and Growth Revisited: An Empirical Note. Journal of Urban Economics, 57. http://dx.doi.org/10.1016/j.jue.2004.12.007

Oates, W. (1995). Federalism and Government Finance. In J. Quigley, \& E. Smolenskey (Eds.), Modern Public Finance (pp. 125-151). Cambridge, Ma.: Harvard University Press.

Oates, W. (1999). An Essay on Fiscal Federalism. Journal of Economic Literature, 37, 1120-1149. http://dx.doi.org/10.1257/jel.37.3.1120

Okigbo, P. (1980). Revenue Allocation and Fiscal Commission. Lagos: FGN Press.

Omotoso, F. (2010). Nigerian Fiscal Federalism and Revenue Allocation Formula for Sustainable Development in Niger Delta. Journals of the Social Sciences, 5(3). http://dx.doi.org/10.3923/sscience.2010.246.253

Putnam, R. (1993). Making Democracy Work: Civic Traditions in Modern Italy. Princeton NJ: Princeton University Press.

Rodden, J. (2003). Comparative Federalism and Decentralization; On Meaning and Measurement. Comparative Politics, 36(4), 481-500. http://dx.doi.org/10.2307/4150172

Rodriguez-Pose, A., \& Krojier, A. (2009). Fiscal Decentralization and Economic Growth in Central and Eastern Europe. Growth and Change, 40(3). http://dx.doi.org/10.1111/j.1468-2257.2009.00488.x

Saibu, O., \& Adedokun, S. (2010). Fiscal Federalism and the Growth of Nigerian Economy (1980-2004). International Journal of Social Sciences, 2(3), 45-53.

Steiner, J. (1995). European Democracies (3rd ed.). New York: Longman.

Ugwu, S. (2012). Fiscal Federalism: The Bane of Socio-Economic and Political Development in Nigeria. Journal of Society for Research and Academic Excellence.

Wheare, K. (1964). Federal Government. New York, Oxford University Press.

\section{Copyrights}

Copyright for this article is retained by the author(s), with first publication rights granted to the journal.

This is an open-access article distributed under the terms and conditions of the Creative Commons Attribution license (http://creativecommons.org/licenses/by/3.0/). 